\title{
TRANSNATIONAL FAMILIES AND MIGRANT MASCULINITIES: THE SOCIAL INSTITUTION OF MALE ADULTHOOD AND FAMILY REUNIFICATION IN THE BANGLADESHI DIASPORA IN ITALY
}

\author{
Francesco DELLA PUPPA
}

COBISS 1.01

\begin{abstract}
Transnational Families and Migrant Masculinities: The Social Institution of Male Adulthood and Family Reunification in the Bangladeshi Diaspora in Italy

This article is the result of a broader research project aimed at analysing the social construction of masculinity of Bangladeshi migrants to Italy. Specifically, the article focuses on the family reunification experience of Bangladeshi migrant men with their wives. Firstly, using some Bourdieusian perspectives, the article analyses the meanings of family reunification for migrants, how it constitutes a fundamental act of the institution of adult masculinity. Secondly, it investigates the meaning of this experience for the migrants' fathers and fathers-in-law in Bangladesh and how it can shape their masculinity according to their embedded habitus and social class position.

KEY WORDS: migrant masculinities, family reunification, Bangladeshi diaspora, Italy, transnationalism
\end{abstract}

\section{IZVLEČEK}

Transnacionalne družine in moškost migrantov: Socialni institut moške odraslosti in združevanje družin v bangladeški diaspori v Italiji

Članek je rezultat obsežnejšega raziskovalnega projekta, katerega cilj je bila analiza družbenega konstrukta možatosti bangladeških migrantov $v$ Italijo. Konkretno gre za izkušnjo združevanja družine na primeru migrantov iz Bangladeša in njihovih žena. Avtor v začetnem delu s pomočjo nekaterih bourdieujevskih konceptov analizira pomen združitve družine, ki je za migrante temeljni akt inštituta odrasle moškosti. V nadaljevanju proučuje pomen te izkušnje za očete in taste migrantov, ki živijo v Bangladešu, kakor tudi njen vpliv na pojmovanje moškosti v skladu z njihovim privzgojenim habitusom in družbenim položajem.

KLJUČNE BESEDE: moškost migrantov, združitev družine, bangladeška diaspora, Italija, transnacionalnost

PhD in Social Sciences, Assistant Professor, Department of Philosophy and Cultural Heritage, International Centre for Humanities and Social Change, Ca' Foscari University in Venice, Malcanton Marcorà, Dorsoduro 3484/D - 30123 Venice; francesco.dellapuppa@unive.it 


\section{INTRODUCTION}

The social construction of gender and the reconstruction of gender experiences of migrant men, especially when viewed in the context of intimate and family life, are research topics poorly studied in the sociological literature.

In the sociology of migration, the male migrant has been the primary subject of investigation for many years, but their gender identity has rarely been analysed. However, studies that have addressed migration from a gender point of view have mainly studied female migration (Anthias, Lazardis 2000; Morokvasic 1984).

At the same time, the growing number of contributions on men's studies that have helped launch new research areas and create a "new intellectual program" (Carrigan et al. 1985; Connell 1996; Hearn 2015; Kimmel et al. 2005) only rarely focus on migrants and, if they do, focus primarily on the working dimension (Batnizky et al. 2009; Shereen et al., 2014; Donaldson et al. 2009), only superficially addressing other aspects of male experience such as family and private life (Bustamante, Alemàn 2007; Parreñas 2008). At the same time, research that focuses on family reunification (Bertolani et al. 2014; Kofman 2014) is quite rarely examined from a male point of view - even if recent works have also addressed male migration through a different epistemological approach as well as a gendered perspective (Batnitzky et al. 2009; Broughton 2008; Bustamante, Alemàn 2007; Della Puppa 2014; 2019b; Gallo and Scrinzi 2016; McKay 2007; Näre 2010; Parreñas 2008; Sarti 2010; Saucedo, Morales 2010; Scrinzi 2010).

Furthermore, studies that focus on the parental dimension of migration tend to give more space to the female perspective (Ambrosini 2014; Boccagni, Bonizzoni 2013; Milharčič Hladnik 2015). As Parreñas (2001) argues, the "pain of transnational parenthood" is a constituent element of migrant women's identities. Therefore, within the analysis of transnational families, migrant women have been observed as mothers, transnational carers and, at the same time, breadwinners for their family members. However, migrant fathers, despite the distance from their family contexts, have only rarely been identified for their transnational family experience and their role as distance carers. In this regard, some important contributions, framing male migration as an experience that redefines the identities of men and their relations with the families left behind, should be mentioned. Parreñas (2008), for example, by observing the family through an "emotional lens" and the intersections between genders and generations, analyses the suffering and embarrassment associated with the loss of confidence between fathers and children. She also analyses the "emotional gap" arising between generations divided by migration and how fathers and mothers manage distance care through various types of "frontering" (Bryceson, Vuorela 2002). In contrast, Bustamante and Alemàn (2007) point out that fathers succeed in preserving their intimacy with their children and overcoming their physical distance to an extent through transnational caring practices similar to those of $\mathrm{mi}$ grant mothers. 
Family life, in its intertwining with work life, is comprised of many experiences that contribute to the construction and redefinition of adult identity. These moments help to redefine the relations of subjects with themselves, with others and with the set of their life experiences, leading them to redefine their self-image and to activate new reflection processes.

The events that accompany and determine the path of the construction of the adult masculine life have been observed as acts of institution (Bourdieu 1982): social constructs that do not involve a mere passage of time (from childhood to adulthood, for example), where the one who undergoes the act of institution is separated from the one who still has to undergo it. These events represent a deeper separation between those who are or will be in a position to undergo them and the ones who will never and in no way undergo these events. Such acts of institution can also effectively intervene in reality, acting on its representations. Their symbolic consecration concretely transforms the consecrated persons: it transforms their image in the eyes of the others and, consequently, the way people act towards them; it transforms the self-perception of the "instituted person" and, therefore, the attitudes and behaviours that this person will feel and that they must have to adapt and modify themselves to this representation and in order to meet the new expectations of them (ibid.). In addition to this Bourdieusian framework, during the research I uncharacteristically used the dramaturgical metaphor (Goffman 1959) as an analytical tool. Italian and Bangladeshi societies, in fact, have been seen as the front stage and backstage of the same representation, depending in their mutual alternation on the placement of the speakers.

The research focused on the case of the Bangladeshi community living in Alte Ceccato, a suburb in the province of Vicenza (Italy). In this village, migrants represent a third of its 6,804 inhabitants and more than half of these were born in Bangladesh (Della Puppa 2015).

\section{METHODOLOGY}

This paper is the result of a broader research project aimed at analysing the transformations of masculinity that take place in the institution of the adult lives of Bangladeshi migrants to Italy (Della Puppa 2014, 2015; Morad, Gombač 2015, 2018). The analysis focuses on a fundamental event in the migration experience: family reunification. This research is based on prolonged periods of participant observation in Italy (almost two years) and Bangladesh (three months) and the collection of 45 in-depth interviews at both poles of migration (Bangladesh and Italy). In Italy I interviewed 25 men who had been reunited with their wives and in Bangladesh 20 male family members of migrants previously interviewed in Italy. The migrants interviewed in Italy belong to the first generation of Bangladeshi migrants in Italy, and are almost entirely composed of urban middle- and upper-middle class men 
or members of quite wealthy rural families, who arrived in Italy in the '90s (ibid.). The decision to interview only men was a specific methodological and theoretical choice. In other words, I tried to gather the experiences and representations of men and to read the gender dynamics as told by men, and to discuss how they represent themselves, their relationships with women and the gender relations within their family. I recognise that adopting this perspective could have limitations; however, this constitutes one of the many different angles from which to observe gender and gender dynamics, and it does not imply gender-blindness - no more than focusing only on women or only on migrant couples or, once again, only on the migrants' relatives would - and I remain sensitive to gender and generational dynamics in my ensuing analysis.

\section{THE FRONT STAGE OF A TRANSNATIONAL BACKSTAGE}

The normative gender constructions that govern the relations between men and women in Bangladeshi society and the practice of arranged marriages force migrants and their wives to meet each other only after their marriage. However, it often happens that because of the job in Italy the newlyweds will meet and share their residence only after reunification. In fact, it should be underlined that, under Italian law (Law 189 of 2002), sufficient income and suitable housing must be available before families can be reunited. Pursuant to this law, the achievement of these is made possible by the labour and the income of the first-migrant applicant ${ }^{1}$ (Della Puppa 2019a). So, from the perspective of Italian society, after having achieved the parameters established by law, the first-migrant applicant applies for reunification with what is identified as his family: having got married - often through an arranged marriage with a woman he met on his return to Bangladesh during his holidays - he and his wife formally constitute a family admitted for reunification. Therefore, what Italian society defines as "family reunification", read through Goffman's dramatic metaphor, represents the proscenium in Italy of a backstage determined in Bangladesh. That is, it is the result of a transnational process that allows the creation from the beginning of a nuclear family and its settlement in Italy. The administrative process that establishes the reunification conceals from Italy the matrimonial dynamics and the family planning of probashi in Bangladesh (Della Puppa 2014).

1 I use the term "applicant" (e.g. "applicant husband") to identify the family member who brought his family members to Italy through family reunification, the term "reunited family member" (e.g. "reunited wife") to identify those arrived in Italy, and the term "first migrant" to identify the family member who first migrated, opening the family "migration chain" (often coinciding with the applicant family member).

2 Bangladesh expats are called probashi, which means "external inhabitants" or "the ones who went out". 
For many people, the reunification can almost be compared to the marriage. The reunifications implemented by the Bangladeshi migrants residing in Alte Ceccato are almost all reunifications completed by men who are beginning their married life and starting to construct intimacy with their wives within the context of immigration: "After the wedding, I stayed with her just thirteen days, too little to get to know each other, you know? Then, after nine months she came in Italy and slowly we got to know each other here" (Zoir).

\section{REUNIFICATION WITH THE WIFE, INSTITUTION AS A MAN}

\section{In the Realignment of the Community}

As family reunification is closely connected with socio-material parameters and, therefore, linked to the work and the efforts of the first-migrant applicant, it constitutes a tangible proof of the migratory, biographical and nuptial success, the proof of becoming an adult and a "moral" man, a thing that allows the migrant to separate himself from the family of origin. Conversely, those who do not carry out a reunification are subject to the censure of their countrymen and to the stigma of the "amoral deviant":

People told me: "It is good if you bring your family here." I was too late: all my old friends had already brought their families before me. I was married for eleven years, they arrived only six months ago. The other people married, and soon after, within two or three years, they brought [their wives]. [There was] nobody like me. [...] All the wives arrived, only my wife didn't. [...] Everyone brought his family, their family, I have to bring my family too. (Samad)

The reunification with the wife establishes a dividing line between a "before" and an "after" in the biography of the migrant man who completes it, and a line of demarcation between those who can perform their role as husband only in Bangladesh and those who can also do so in the bidesh. ${ }^{3}$ In this act of institution, however, there is an even deeper and more invisible distinction between those who may have access to the bidesh as a "first migrant" and those who can have access to it only after the reunification, between those who have carried out a reunification and those who have been subjected to it. The institution, therefore, confers on individuals the typical social dynamics of the diaspora (Farahani 2012) and its reproduction through migratory

3 In Bangla it means "foreign land", foreign countries, as opposed to the Bangla-desh, "The country, the land where Bangla is spoken". 
chains started by men; it separates men from women, according to the gender norms that characterize the migration from Bangladesh to Southern Europe. ${ }^{4}$

\section{Compared to the Society of Origin: the Father and the Father-in-Law}

In Bangladesh, after having supported the marriage of a daughter with a probashi, the bride's parents - especially if they belong to the middle class - expect that the son-in-law will perform the family reunification, in order to free his wife from her subordinate relationships of patrilocality, ${ }^{5}$ to share with her the living standards and the better opportunities provided by migration in Europe, and to show his (and their) male honour by protecting and controlling his wife.

Everyone asked my wife:"Why doesn't your husband take you to Italy?"They said that it was not right that we were separated. Because in her family other people went to bidesh and everyone brought their wife. Her sister-in-law, the wife of her brother, for example, said to her: "Your husband will bring you in Italy when the sun rises in the West." Get it? She said that I would only bring her when the sun goes the wrong direction. She meant: "He'll never bring you, don't believe your husband." (Sharif)

Sometimes, the institution of adult life through reunification symbolically takes place against the father's will. In fact, the transfer of the bride from the extended family in Bangladesh to the nuclear one in Italy may lead to a break with the father's influence on a symbolic and on a material level: on a symbolic level because the migrant becomes directly responsible for his family and his reunited wife, subtracting this power from the father; on a material level because the reunification may necessitate a reduction in remittances sent to the family of origin. But despite this symbolic conflict, sometimes it is the parents of probashi that hope for reunification. In fact this event, which makes it possible for the son who emigrated to become a man, also allows his father in Bangladesh to fulfil his family duties and complete a further life step.

The discussion about the patrilocal norm - that is present in Bangladesh, among educated middle-class girls - can push the father-in-law's family to oppose the reunification of the daughter in Italy, in order not to lose the power over her and in order not to have to give up the remittances it takes possession of through the daughter. Therefore, in this case the entrance into adulthood of probashi happens against the father-in-law's will.

4 In which the "first migrant", in almost all cases, is a man.

5 We must not forget that in Bangladesh, especially in rural areas, there is a relatively rigid patrilocal law that dictates that the new couple - or only the bride, if the groom is a probashi - go to live in the house of her husband's family, where the families of his brothers-in-law also live, and where the young bride will have to support all of the family members. 


\section{REUNIFY THE WIFE, AND REUNIFY THE HUSBAND. MEANINGS OF AND MOTIVATIONS FOR REUNIFICATION}

\section{"To Start Your Life"}

Life before family reunification is represented as a preparatory phase, a "run-up to the jump into life", or simply as a "non-life". Therefore, the reunification effectively marks the beginning of a life that is worth living, a life surrounded by family: "Two parts, two separate people: this is not life. I'm married, I need to be with my wife, not always my wife in Bangladesh and I here. Now, when I'm with my wife, with my son, I hug him, I kiss him ... this is life! A life without love is nothing, zero. Before it wasn't life, now it's fine" (Samad).

Family reunification is represented as a goal that must be reached in the shortest possible time, without "wasting time": in fact, any other approach would render the marriage meaningless, part of the efforts and sufferings of migration would become useless and, above all, the "beginning of life" as an adult man would be delayed.

\section{The Suffering of the Lonely "Probashi"}

One of the main motivations for reunification is the migrants' need to create and cultivate an emotional sphere in the immigration context, in order to break the loneliness of the diaspora. In fact, the first inclusion in the immigration context remains restricted to the working sphere. Reduced to mere workforce for the factories of the district, migrants miss the family routine, and feel the burden of their emotional loneliness and of the boredom that characterizes their "free" time:

My life before was different: I was alone. When your family is far from you, in another country and you're here ... you can't see them, you cannot speak with your wife ... it is not good for a human being. I was always lonely and unhappy, I had mental frustration. I was always wondering: "When she will come here? When she will come here?" [...] So many tensions in my mind. (Shantu)

In addition to filling the emotional void, reunification allows for a break in the sexual loneliness of "first migrants", ${ }^{6}$ the regaining of possession of the body and of the emotional sphere, and allows them to distance themselves from the reduction to mere workforce and the condition of "temporary guest worker": "This is not life, the husband here, always working, sending money and doing so [mimes the act of male masturbation], and your wife is alone in Bangladesh! (Samad).

6 A dimension that sociology has scarcely studied with regard to "female migration". 
The desire to be reunited with the wife is also born from the needs of daily organization and the balance between work and family, from the push from adaption to the experienced daily routine to an ideal model of family, economic and work organization: "For me, a family is a great thing. You come home from work and my wife has done everything at home. When I was alone, I had to clean the house and cook for myself, do everything. But now when I come home I see my son, my daughter, my wife has done everything at home. For me it is a new surprise every day" (Tariq).

With reunification the domestic sphere finally becomes a space in which relaxation and leisure time becomes a time of "unedited" normality in which migrants can enjoy recreation and relax, and they begin to feel "at home", even in Alte Ceccato.

\section{Between Enfranchisement and Precept}

As noted above, since the patrilocal norm imposes the "migration" of the bride from her family to her husband's family after marriage, this norm puts the woman in a subordinate position with her in-laws. The risk that the wife of a probashi must submit to the other family members is greater because the husband, her only protection bond in a foreign environment, is absent. "In Bangladesh, my mother wanted to command my wife because the tradition says so. If my wife is there she has to cook, clean, work at home ... so many things. But here, my wife, who controls it? Nobody! She is happy here, not there. No one likes to be controlled." (Rana)

For the wives who remained in Bangladesh, in addition to the obligation of obedience to the father-in-law's family, there are also limitations on women's movement in public that strongly characterize the Bangladeshi reality. Especially in rural areas, women cannot freely move in public places unless they are accompanied by their husband or a male family member. In contexts where such a degree of autonomy may be more negotiated, for example in urban educated families, the freedom of the women may be blocked by a sense of insecurity that, especially in some late hours of the day, imposes a kind of informal curfew. "In Bangladesh, they have many obligations, their life is a bit 'blocked'. [...] Another problem is that in my country it is not safe for women to go out after eight in the evening. But here in Italy, if a woman goes out even at ten it's not a problem." (Zaeed)

The limitations on women's mobility can be reflected onto the children whose movements are tied to the mothers: if the left-behind wives have fewer opportunities to go out because their husbands are absent, their children will also suffer, and as a result, they face similar restrictions:

In Bangladesh, a father can easily go out with his son, the wife cannot. Here women can go out alone everywhere, it is normal, there not. Your wife cannot go out without you. [...] And also [for] your son there are problems because he always has to be at 
home. [...] A son in Bangladesh can go out with his mother, but how often can his mother go out? Rarely. (Samad)

Family reunification, then, is perceived by the respondents as a duty towards their wife and children who remained at home: towards the wife because in this way she is no longer controlled and subordinated to the patrilocal norm; towards their children, because the husband's absence imposes on them a partial state of orphanhood and a limited ability to socialize.

I was talking with my son only always on the phone: "Hello, how are you? How are you Dad?" This is not normal, he did not know who was his dad. [...] My wife said to me: "Your son should grow up near you, with his daddy." For a son, it's not good to grow up without dad, he doesn't grow up normally. [...] A child needs two parents, a father and a mother; a single parent is not good! The child looks at the other dads, but his dad is not there, why? His mother, my wife, works at home, cooks, brings the child to school, reads books, teaches him to write a, b, c ... and I lose everything. She can't always do everything by herself! (Kobir)

Kobir's words reveal remorse for the time spent away from the family, for the separation from his wife to which whom the child's upbringing is entirely delegated, for the suffering inflicted on the child without the paternal reference, and for his own suffering as an immigrant father deprived of the moments that accompany the growth of the child (Abbatecola 2010; Bustamante, Alemàn 2007; Parreñas 2008).

Family reunification, however, can also be seen as an attempt at reassertion of male authority, if the husband comes from a poorer family than that of the wife. The husband's condition of probashi is an element of strength in the process of marriage arrangement and negotiation in order to fill the possible economic gap between the families of the aspiring couple. A definitive return to Bangladesh by the migrant would re-establish the initial gap and would force the husband to accept the symbolic and material subordination to the family of the in-laws. From the point of view of the husbands, then, the married life of the couple must unfold in a context in which the economic and power balance can remain unchanged for the benefit of the male component.

If my wife and I were in Bangladesh now everything would be different. Or she or me. In my country if the husband's family is economically weak and the wife's family is rich, the husband is always under the wife's family, and he is always a bit "weak". The man does not always decide everything. If the family of the woman is richer, the woman dominates. (Zaeed)

Thus, with family reunification Zaeed tries to preserve the patriarchate threatened by the economic domination of the father-in-law's family. In this representation, the 
wife does not represent herself but her family, a presence from which the probashi himself has tried to break free.

The reunited wife, after living through the abrupt transition of the migration from her familial context to the father-in-law's family, has to deal with the trauma of migration to Italy. For women, the arrival in Alte Ceccato, may in fact lead to a profound destabilization: the migration involves multiple status changes and also sudden changes in social and family environment and life, causing pain and disorientation, loneliness and suffering: "When she came here, first two years she didn't want to stay here, she used to tell me: 'Send me to Bangladesh, send me back!' I was trying to let her understand: 'If I need money to live, I have to work here. So, if I work here and I live here, you will stay here.' So, little by little, she starts to understand" (Tanvir).

If upon reunification the house becomes the centre of the emotions for men, a privileged space where the migrant husband can enjoy and regain his family after work, for the reunited wives the boundaries of the house could become a golden cage and a place of suffocation and loneliness.

In contrast, in the country of origin, the wives spend their days in the relational context of the extended family of the absent husband. On the one hand, this may lead to subordination to the power of the mother-in-law, of other sisters-in-law and, more generally, of the other family members; on the other hand, however, the husband's family may provide the new bride with a dense network of relationships that is not segregated: in fact, there can be bonds of confidence and complicity between the women of the house. The strict hierarchy among members of her husband's family, the control and oppression to which the young daughter-in-law would be subject, can coexist and be reconciled with ties of solidarity, domestic warmth and family protection.

As a result of the broad extension that characterizes the family structure in Bangladesh (Gardner 1995), especially in rural areas, the wives left behind in Bangladesh, while respecting the precepts of purdah, ${ }^{7}$ also have a chance to enjoy some close interpersonal and family ties. At the moment they are reunited, however, the desire to maintain the embedded rules governing their movements can make their social space coincide with the home space or limited portions of it. The vivacity of family ties and the family environment of origin gives way to the solitude of a yellowed room or a dilapidated apartment where the young brides find themselves living with an unknown husband or with one with whom there is no way and time to construct any intimacy. The same interviewees describe the suffering imposed on the wives

7 Literally "veil" or "curtain", it refers to a set of built-in practices that contribute to the construction of "modesty", "honour" and "shame", and preserves the separation, symbolic or material, of gender and spheres of gender activities through clothing, daily practices, the structuring of domestic environments, and physical segregation. To observe the requirements of purdah means to maintain the separation (more or less rigid) of domestic spaces along gender lines and observe the ban on access to public spaces in the absence of a male family member. 
who, after being all alone during the day, can only have a few moments of the spouse's company when he comes back home exhausted after a long work shift:

In Bangladesh, she lives one type of life, but in Italy she has to live another type of life: the husband works all day, and when he comes back home at night or in the evening he's too tired, after dinner he goes to bed and the woman feels a little frustrated. Frustrated because her time is just passing: her husband works all day, in the evening he takes his food and goes to bed, while the woman is home all day; it is hard for her to pass the time until night when her husband comes home, perhaps they meet each other for one hour, then the husband goes to bed and the woman has nothing to do. (Zoir)

The realization of such an imposition on his wife makes Kazi doubt his wife's love, a love that might be maternal, but not conjugal. His dream of a nuclear family, a "modern" and happy family, pursued through reunification, crumbles under the blows of the compulsion that he acted out through the reunification. His strategy to put an end to his "personal tragedy" is to increase his patriarchal and male domination, that in this way becomes the cause of and (illusory) solution to his dissatisfaction as a man.

I like it here, I do not want to leave my children and my wife there. My heart does not feel good without them. I cannot live without them. Without the sun I cannot live like I cannot live without them. My wife yes. Because I have two things: children and wife. But she does not think of me, she just thinks about them. She has only them. She wants to go to Bangladesh and be there with them. But I do not. I want them here. [...] I want children and her with me. She does not want [this]. [...] But I decide. Because I'm in charge and when I'm in charge she says she's fine. She does not command me! I command her. (Kazi)

A huge hive-condo residential area marked by time does not in fact correspond to the ideal of modern and cosmopolitan Europe as described by the stories of migrants who return to Bangladesh, or as represented on the satellite TV channels that show the famous Brick Lane in London: the central artery and the heart of Tower Hamlets, the home of the largest probashi community in Europe. So the reunited wives must suffer the collective misconception of the migration truth (Sayad 1999) and, moreover, being originally educated daughters and daughters-in-laws of the Bangladeshi upper-middle class, they find themselves as wives of unskilled workers, placed at the lowest level of civic and social stratification. 


\section{REUNIFICATION AS SEEN FROM BACKSTAGE}

\section{Shame and Humiliation for some Men ...}

Some relatives of the migrants interviewed in Bangladesh report that the probashi condition can cause greater difficulties in finding a bride in the country of origin:

When someone comes from abroad and wants to marry someone here it becomes problematic, because the perceptions of probashi are not always favourable. Take for example the "guardian" of a daughter: he might think that his would-be son-in-law is doing a not respectable job: cleaning the streets, working in a hotel, working in a factory, as a carpenter, hard jobs, laborious, not so well-paid, and considered socially humiliating. Because socially it could be humiliating for someone for his daughter to marry someone who does these kinds of jobs. (Shafiq, brother) ${ }^{8}$

For Bangladeshi upper-middle class families, and especially for their male members, to allow a daughter to marry a worker or a labourer would be a humiliation and a disgrace. To be an unskilled wage worker, even in a factory in Europe, can in fact be considered a degrading condition in the eyes of high-status Bangladeshi families of the candidate brides. At the same time, probashi do not always manage to soften (or hide) from their country their real status in the bidesh.

Ali, the owner of a prestigious restaurant chain and a famous cafe in Dhaka, declined to face what is probably perceived as a humiliation to him: in spite of initially agreeing, he did not want to be interviewed about the reunification in Italy of his sister, who married Zaeed, a metalworker in Alte Ceccato, repeatedly refusing to answer the phone on subsequent occasions.

It is conceivable that the probashi has managed to create an idealized representation of his situation in Italy at the time of the marriage negotiation, and managed to marry a woman of superior status. Alì did not want to be interviewed about these issues, trying to avoid an event he considered as humiliating with the researcher. The researcher, having crossed the border between the front stage and the backstage of migration and reunification, would have been aware of Zaeed's situation in Italy, and also of the status in Bangladesh of the family of origin of the woman married to the probashi.

Khan, the father-in-law of a man who emigrated to Italy, considers the marriage of his daughter humiliating and says that he reluctantly agreed to it in order to please his daughter, but he opposed reunification, trying in this way to limit the dishonour. Also the remittances sent to his daughter - living in her father's house - are perceived as a continuous recurrence of such humiliation:

In the interviews, kinship relationships relate to the migrant residing in Italy. 
My son-in-law is living in Italy, but I was reluctant about my daughter's marriage. There was a large number of candidates: a government employee, a doctor, and someone else with a similar status, but my daughter didn't choose them, so I had to get her married to that person that has been working in Italy. [...] I let my daughter go abroad only for her studies, not for any other reason! [...] Of course my son-in-law used to take care of my daughter and so far I know he used to send money to my daughter, but I don't want to intervene in their family life, they're living their life and I am not in need of their money and I don't even want to know how much money is coming from Italy: I don't exactly know and I don't want to know. It is one of my irritations. (Khan, father-in-law)

Khan, who opposes the reunification of his daughter and his son-in-law, reiterates the role of the guardian authority of the family and depicts a clash between patriarchates from which he emerges as the winner. Despite the fact that he defines the division of his daughter's family as a cause of suffering, the possibility of reunification in the bidesh is no way contemplated:

I love my grandchild very much and nothing in the world right now is more dear to me than my grandchild. I love him very much, very, very much; he's now an inseparable part of my life. But I simply don't like that my son-in-law is staying in Italy: I want my daughter and my son-in-law to be united, but practically now it is not possible, it's a matter of grievance for me. (Khan, father-in-law)

\section{... Honour, Success and Prestige for Others}

For other men, however, the condition of successful migrants (and, therefore, of potential reunification of candidate husbands) has been the key element of the marriage. Rahaman, for example, had always proposed the marriage of his daughter to a probashi. The interviewee does not see possibilities for the future of the new generations belonging to lower-middle class families - like his - in Bangladesh, and believes that only emigration can guarantee them better opportunities. For his daughter, however, the only socially legitimate way to implement this project is to marry a migrant and be reunited.

I have always wanted to let my daughter marry someone who lives abroad, because the prevailing conditions in our country are bad and - I think - will be worse within a short period, so for the future of my offspring, I decided to give my daughter to a probashi. [...] The fact that he was in Italy was - of course - a positive point, a plus. It prompted us to push our daughter to marry him. (Rahaman, father-in-law) 
The realization of what is perceived as a particularly advantageous marriage (and makes the emigration to Europe possible) confers honour and prestige on the representative - "the guardian" - of the bride's family. Through his daughter's marriage and her stabilization in Europe, Rahaman feels that he has completed his parental obligations, and that he has completely fulfilled his patriarchal duties and therefore has actualized himself as a father and a man.

The sacrifice of two generations (his own and his daughter's), consisting of the wound of emigration and the suffering of family separation, would be justified by the realization of future generations that through their successes in the bidesh the prestige of the family and its representatives will be immortalized, along the chosen male line.

In Europe or in America you could find some sort of assurance of living conditions. When someone is living in Italy or somewhere in Europe, the next generation will get some more opportunities to get a good education and to be a citizen of that country, so these were the things on my mind when I thought to marry my daughter to someone living there. (Rahaman, father-in-law)

For those that an interviewee defines as "middle-class educated families", the mere presence of the son-in-law abroad and the economic benefits of the remittances do not constitute sufficient conditions to justify a marriage of this kind. To marry a migrant, in fact, is not a "convenient" union by virtue of its immediate economic benefits (remittances), but because of the most optimistic possibilities of life that it would offer to the reunited wife and the future generations.

The separation of husband and wife would prevent their living as a whole family and the individual realization of the bride, who would remain at home despite being married to a man abroad, and who would go to stay in the house of her husband's family where she would risk being placed in a position of subordination, vulnerability and loneliness. The remittances, aimed partly at supporting his wife and children, could be managed in their entirety by her husband's family. If not followed by family reunification, therefore, marriage to a migrant can be transformed from a symbol of success and prestige to a stigma of failure for the whole family and, above all, for the head of the family that represents it and is responsible for it. "It was only when I realized that my son-in-law intended to bring my daughter along with him that I didn't object to the marriage" (Rahaman, father-in-law).

Because - in Bangladesh, but also in other nations - the position of each member of the family in the marriage market depends on the marriages of all the others, the favourable marriage of the eldest daughter could result in an improved position in the marriage market of the second daughter, who will then have more possibilities for a favourable marriage, thereby maximizing Rahaman's realization as a man.

While for upper-middle class men who come from prestigious families the marriage of a daughter or a sister to a migrant can be a form of social devaluation, 
for middle-class men who, even though they have sufficient capital, cannot boast membership in a clan of noble origins, a marriage of this kind can be an opportunity for upward social mobility (Gardner 1995) and, therefore, for an increase of male honour. For Rahaman, however, when this objective finally appeared to have been achieved, his hopes of a bright future for his daughter were frustrated by the effects of the economic crisis:

But immediately after the marriage of my daughter I found that in Italy the situation is not going so well. My son-in-law has been staying in Italy for more than ten years and just in 2008 things began change rapidly, and now they find that is tough to stay in Italy with the family. Socially our condition is very ridiculous, because our relatives, friends, neighbours and everyone think that since my son-in-law lives in Italy he must be of great help to my family, all of them think that he sends remittances on regular basis and when I talk to them then I also recognize this [as a] fact; I say that and I act as if my son-in-law is a great help for us. I used to confirm this, because socially it would be a problem if I said things in another way. So I used to tell another truth, I used to tell the opposite from what the reality is. So socially I should say I need to say the opposite from what is actually happening. (Rahaman, father-in-law)

Therefore, the decrease in real job opportunities in Italy and the impossibility of a real improvement in the lives of emigrated relatives caused by the recession aggravated the suffering of migration. For Rahaman, the staging in Bangladesh of different representations compared to the stories provided by the daughter in Italy becomes an extreme form of resistance to the loss of meaning of a life spent away from the family, but, above all, a strategy to avoid compromising the male honour and the family respectability gained through a marriage that was still favourable in the eyes of the community, and not to lose the social currency that is useful to the marriage prospects of his still-marriageable younger daughter.

\section{CONCLUSIONS}

The experience of building a nuclear family in the diaspora through the process of family reunification is configured as a real act of the institution of adulthood (Bourdieu 1982) through which probashi become men in the eyes of communities of their compatriots in Italy and in the comparison - even if conflicting - with the father and the father-in-law (the status of male relatives is also increased by the experience of the migrant) in Bangladesh.

By intertwining the representations - constructed "with male voices" - about the dynamics and hierarchies that characterize the organization of the family in Bangladesh with those relating to the condition of reunified wives in Alte Ceccato, it has been possible to elicit the ambivalence of reunification and the often contradictory 
experiences that accompany it. This event represents an opportunity through which the probashi can realize his emotional and family dimension in migration, but also a duty that he feels he must fulfil towards his wife in order to free her from the patriarchal power of the extended family, and finally also a form of symbolic violence by him on the reunited wife - a component of masculine domination from which he is unable to free himself (Bourdieu 1998). At the same time, if observed from the perspective of the migrants' country of origin, the reunification through the migration of their wives can be a family wound full of suffering - the result of a patriarchal strategy aimed at increasing the honour of the women's families, and especially, of their representatives, and on the contrary, a potential source of humiliation and dishonour for them due to the class position and the habitus of the social actors. So the class position, transnational strategies and social constructions of masculinity intersect each other (Christensen, Sune Qvotrup 2014; Farahani 2012; Hearn et al. 2013), leading to the creation of profiles of men who are sometimes locked into the dominant representation that forces them into the differentiation of the social forms of gender construction; they are dominated by their own dominion, rather than by the desire to dominate. The construction of representations within rigid gender boundaries, in fact, does not structure only the dominated, but also the dominators, and is also subject to a control device that regulates their expression. Honour - warns Bourdieu (1998) - governs the honourable man: he cannot obey this imperative without denying himself.

\section{REFERENCES}

Ambrosini, Maurizio (2014). Parenting from a Distance and Processes of Family Reunification: A Research on the Italian Case. Ethnicities 8, 1-20. DOI: $10.1177 / 1468796814547059$.

Anthias, Floya, Lazardis, Gabriella (2009). Gender and Migration in Southern Europe. Oxford: Berg.

Batnitzky, Adina, McDowell, Lybda, Dyer, Sarah (2009). Flexible and Strategic Masculinities: The Working Lives and Gendered Identities of Male Migrants in London. Journal of Ethnic and Migration Studies 8/35, 1275-1293. DOI: 10.1080/13691830903123088.

Bertolani, Barbara, Rinaldini, Matteo, Tognetti Bordogna, Mara (2014). Combining Civic Stratification and Transnational Approaches for Reunited Families: The Case of Moroccans, Indians and Pakistanis in Reggio Emilia. Journal of Ethnic and Migration Studies 9/40, 1470-1487. DOI: 10.1080/1369183X.2013.868302.

Boccagni, Paolo, Bonizzoni, Paola (2013). Care and Circulation Revisited: A Conceptual Map of Diversity in Transnational Parenting. Transnational Families, Migration and the Circulation of Care (eds. Loretta Baldassar, Laura Merla), 78-94. Adergate: Routledge. 
Bonizzoni, Paola (2012). Civic Stratification, Stratified Reproduction and Family Solidarity: Strategies of Latino Families in Milan. Gender, Generations and the Family in International Migration (eds. Albert Kraler, Martin Kohli, Camille Schmoll), 311335. Amsterdam: Amsterdam University Press.

Bourdieu, Pierre (1982). Les rites comme actes d'institution. Actes de la recherche en sciences sociales $43,58-63$.

Bourdieu, Pierre (1998). La domination masculine. Paris: Le Seuil.

Broughton, Chad (2008). Migration as Engendered Practice: Mexican Men, Masculinity, and Northward Migration. Gender and Society 22/5, 568-589. DOI: 10.1177/0891243208321275.

Bryceson, Deborah, Vuorela, Ulla (2002). The Transnational Family: New European Frontiers and Global Networks. Oxford: Berg.

Bustamante, Juan Josè, Alemàn, Carlos (2007). Perpetuating Split-household Families: The Case of Mexican Sojourners in Mid-Michigan and their Transnational Fatherhood Practices. Migraciones Internacionales 1/4, 65-86. DOI:10.1068/ a44128.

Carrigan, Tim, Connell, Bob, Lee, John (1985). Toward a New Sociology of Masculinity. Theory and Society 14, 551-604. DOI: 10.1007/BF00160017.

Christensen, Ann-Dorte, Sune Qvotrup, Jensen (2014). Combining Hegemonic Masculinity and Intersectionality. Norma: Nordic Journal for Masculinity Studies 9/1, 60-75. DOI: 10.1080/18902138.2014.892289.

Connell, Raewyn (1995). Masculinities. Cambridge: Polity Press.

Della Puppa, Francesco (2014). Uomini in movimento: Il lavoro della maschilità fra Bangladesh e Italia. Torino: Rosenberg and Sellier.

Della Puppa, Francesco (2015). Home Between bidesh and shodesh: Domestication of Living Spaces, Identity and Gender Experiences in the Bangladeshi Diaspora. Dve Domovini / Two Homelands 42/2, 97-111.

Della Puppa, Francesco (2019a). Bodies at Work, Work on Bodies: Migrant Bodies, Wage Labour, and Family Reunification in Italy. Journal of International Migration and Integration. DOl: https://doi.org/10.1007/s12134-018-00644-x

Della Puppa, Francesco (2019b). A Redeemed Biography? Migration as an Intra-family Redemption Device. Rassegna Italiana di Sociologia 1 (forthcoming).

Donaldson, Mike, Hibbins, Raymond, Howson, Richard, Pease, Bob (2009). Migrant Men: Critical Studies of Masculinities and the Migration Experience. Aldergate: Routledge.

Farahani, Fataneh (2012). Diasporic Masculinities: Reflections on Gendered, Raced and Classed Displacements. Nordic Journal of Migration research 2/2, 159-166. DOI: 10.2478/v10202-011-0038-5.

Gallo, Ester, Scrinzi, Francesca (2016). Migrant Men, Masculinities and Reproductive Labour: Men of the Home. Basingstoke: Palgrave.

Gardner, Katy (1995). Global Migrants, Local Lives: Migration and Transformation in Rural Bangladesh. Oxford: Oxford University Press. 
Goffman, Ervin (1959). The Presentation of Self in Everyday Life. New York: Anchor Books. Hearn, Jeff (2015). Men of the World: Genders, Globalizations, Transnational Times. London: Sage.

Hearn, Jeff, Blagojevic, Marina, Harrison, Katherine (2013). Rethinking Transnational Men: Beyond, Between and Within Nations. Aldergate: Routledge.

Kimmel, Michael, Hearn, Jeff, Connell, Raewyn (2005). Handbook of Studies on Men and Masculinities. Oaks: Sage.

Kofman, Eleonore (2004). Family-Related Migration: A Critical Review of European Studies. Journal of Ethnic and Migration Studies 30/2, 243-262. DOI: 10.1080/1369183042000200687.

McKay, Strven C. (2007). Filipino Sea Men: Constructing Masculinities in an Ethnic Labour Niche. Journal of Ethnic and Migration Studies 33/4, 617-633.

Milharčič Hladnik, Mirjam (2015). From Slovenia to Egypt: Aleksandrinke's Trans-Mediterranean Domestic Workers' Migration and National Imagination. Göttingen: V\&R.

Morad, Mohammad, Gombač, Jure (2015). Transmigrants, Transnational Linkages and Ways of Belonging: The Case of Bangladeshi Migrants in Italy. Dve Domovini /Two Homelands 41, 61-76.

Morad, Mohammad, Gombač, Jure (2018). "Probashi" in Italy. New Destinations: Trends, Origins and Profiles of Bangladeshi Migrants in Padova and Cadoneghe. Dve Domovini / Two Homelands 47, 37-52.

Morokvasic, Mirjana (1984). Birds of Passage are also Women .... International Migration Review 4, 886-907. DOI: 10.2307/2546066.

Näre, Lena (2010). Sri Lankan Men Working as Cleaners and Carers: Negotiating Masculinity in Naples. Men and Masculinities 13/1, 65-86.

Parreñas, Rhacel Salazar (2001). Servants of Globalization: Women, Migration, and Domestic Work. Stanford: Stanford University Press.

Parreñas, Rhacel Salazar (2008). Transnational Fathering: Gendered Conflict, Distant Disciplining and Emotional Gaps. Journal of Ethnic and Migration Studies 7/34, 1057-1072. DOI: 10.1080/13691830802230356.

Sarti, Raffaella (2010). Fighting for Masculinity: Male Domestic Workers, Gender, and Migration in Italy from the Late Nineteenth Century to the Present. Men and Masculinites 13/1, 116-143.

Saucedo, Leticia M., Morales, Cristina (2010). Masculinities Narratives and Latino Immigrant Workers: A Case Study of the Las Vegas Residential Construction Trades. Harvard Journal of Law and Gender 33/2, 625-660.

Sayad, Abdelmalek (1999). La double absence: Des illusions aux souffrances de l'immigré. Paris: Seuil.

Scrinzi, Francesca (2010). Masculinities and the International Division of Care: Migrant Male Domestic Workers in Italy and France. Men and Masculinities 13/1, 44-64.

Shereen, Hussein, Mohamed Ismail, Manthorpe, Jill (2014). Male Workers in the Female-dominated Long-term Care Sector: Evidence from England. Journal of Gender Studies 25/1, 35-49. 


\section{POVZETEK}

\section{TRANSNACIONALNE DRUŽINE IN MOŠKOST MIGRANTOV: SOCIALNI INSTITUT MOŠKE ODRASLOSTI IN ZDRUŽEVANJE DRUŽIN V BANGLADEŠKI DIASPORI V ITALIJI Francesco DELLA PUPPA}

Članek analizira družbeni konstrukt moškosti bangladeških migrantov v Italijo. Konkretno gre za izkušnjo združevanja družine na primeru migrantov iz Bangladeša in njihovih žena. Avtor v začetnem delu s pomočjo nekaterih bourdieujevskih konceptov analizira pomen združitve družine, ki je za migrante temeljni akt inštituta odrasle moškosti. $V$ nadaljevanju proučuje pomen te izkušnje za očete in taste migrantov, ki živijo v Bangladešu, kakor tudi njen vpliv na njihovo pojmovanje moškosti v skladu z njihovim privzgojenim habitusom in družbenim položajem. Poleg bourdieujevskega okvira je avtor $v$ raziskovalni študiji kot analitsko orodje na poseben in neznačilen način uporabil dramaturško metaforo. Italijansko in bangladeško družbo je predstavil kot oder in zakulisje iste zgodbe, ki se medsebojno izmenjujeta glede na položaj govorcev. Empirično gradivo za pričujoči članek sestavljajo daljša obdobja spremljanja udeležencev tako $v$ Italiji kot v Bangladešu ter 45 poglobljenih intervjujev, izvedenih v obeh državah.

Izkušnja ustvarjanja nuklearne družine, selitev in združitev družine so predstavljene kot dejanski akt instituta odraslosti, s pomočjo katerega migranti postanejo možje v očeh rojakov v Italiji, kakor tudi v primerjavi - čeprav konfliktni - z očetom in $\mathrm{s}$ tastom (moških sorodnikov, ki jih je prav tako zaznamovala izkušnja migranstva) v Bangladešu. Združitev družine je za migranta priložnost, da zaživi svoje čustveno in družinsko življenje, hkrati pa tudi dolžnost do žene, ki jo mora izpolniti, da bi jo osvobodil patriarhalne moči razširjene družine. Navsezadnje je združitev družine tudi nekakšna oblika simboličnega nasilja nad pridruženo ženo - komponenta moške dominacije, ki se je migrant ne more osvoboditi. Združitev družine je, če jo opazujemo iz migrantove domovine oziroma dežele izvora, lahko tudi zelo boleča družinska rana, posledica patriarhalne strategije, ki naj bi prispevala k časti ženine družine in njenih moških predstavnikov, po drugi strani pa je lahko tudi vir ponižanja in sramote, kar je odvisno od razrednega položaja in habitusa družbenih akterjev. Razredni položaj, transnacionalne strategije in družbeni konstrukti moškosti tako tvorijo nekakšen presek, ki generira osebnostni profil moških, včasih tako vklenjenih v svojo potrebo po dominaciji, da jih ta sili v diferenciacijo družbenih oblik ustvarjanja spola; bolj jih vodi lastna predstava o nadrejenosti kot želja po obvladovanju. Konstrukcija predstav znotraj togih spolnih meja, ki ne strukturira le podrejenih, ampak tudi nadrejene, je prav tako podvržena vzvodom nadzora, ki vplivajo na njeno izražanje. 